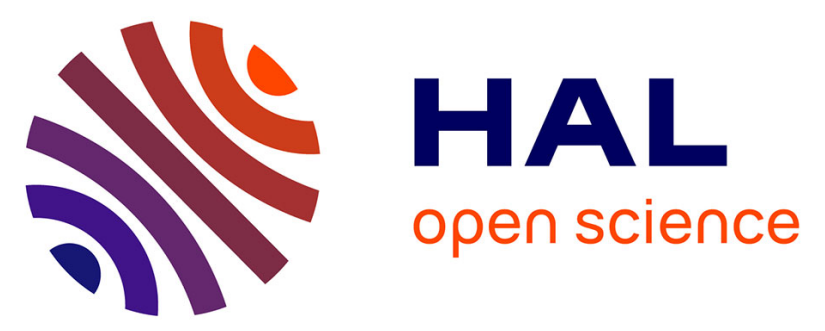

\title{
Influence of light, water stress and shrub cover on sapling survival and height growth: the case of A. unedo, F. ornus and S. domestica under Mediterranean climate
}

Manon Helluy, Jordane Gavinet, Bernard Prévosto, Catherine Fernandez

\section{- To cite this version:}

Manon Helluy, Jordane Gavinet, Bernard Prévosto, Catherine Fernandez. Influence of light, water stress and shrub cover on sapling survival and height growth: the case of A. unedo, F. ornus and S. domestica under Mediterranean climate. European Journal of Forest Research, 2021, 140, pp.635-647. 10.1007/s10342-021-01356-1 . hal-03179371

\section{HAL Id: hal-03179371 \\ https://hal-amu.archives-ouvertes.fr/hal-03179371}

Submitted on 17 Jun 2021

HAL is a multi-disciplinary open access archive for the deposit and dissemination of scientific research documents, whether they are published or not. The documents may come from teaching and research institutions in France or abroad, or from public or private research centers.
L'archive ouverte pluridisciplinaire HAL, est destinée au dépôt et à la diffusion de documents scientifiques de niveau recherche, publiés ou non, émanant des établissements d'enseignement et de recherche français ou étrangers, des laboratoires publics ou privés. 


\title{
Influence of light, water stress and shrub cover on sapling survival and height growth: the case of $A$. unedo, $F$. ornus and $S$. domestica under Mediterranean climate
}

Manon HELLUY ${ }^{1,3 *}$, Jordane GAVINET ${ }^{2}$, Bernard PREVOSTO $^{1}$, Catherine FERNANDEZ $^{2}$

*corresponding author

${ }^{1}$ INRAE, Aix-Marseille Université, UMR RECOVER, 3275 Route de Cézanne, F-13182 Aix-en-Provence, France

${ }^{2}$ IMBE, Aix Marseille Université, Avignon Université CNRS, IRD, UMR 7263, 3 place Victor-Hugo, F-13331 Marseille cedex 3, France

${ }^{3}$ ENGREF, AgroParisTech, France

E-mail addresses: manon.helluy@inrae.fr (M. Helluy); jordane.gavinet@outlook.fr; bernard.prevosto@inrae.fr (B. Prévosto); catherine.fernandez@imbe.fr (C. Fernandez)

\begin{abstract}
Resprouter species are of great interest for Mediterranean forest resilience as they can survive fire or drought by activating dormant vegetative buds to produce regrowth. Understanding which factors control the early growth and survival of these species are needed to develop strategies to enhance stand resilience. In this study, three broadleaved resprouter species, two trees - Fraxinus ornus and Sorbus domestica - and a shrub - Arbutus unedo - were planted under a gradient of pine cover. Sapling survival and height growth were monitored for 6 years, 2 years after their plantation, as well as light and shrub cover. We developed a two-strata forest water balance model, which produces a water stress index. We aimed to determine the effect of light, water stress and shrub cover on sapling survival and height growth using a modelling approach. We found that high levels of transmittance had a negative impact on both survival and height growth of $F$. ornus and $S$. domestica, while it had a positive effect on A. unedo growth. Water stress was found to negatively affect survival and height growth of all species. Lastly, shrub cover had an overall positive effect on the survival and growth of saplings, indicating a facilitating effect of the shrubs. Our results suggest that shade-tolerant tree species like F. ornus and $S$. domestica are more suited to moderate and light cover, while photoinhibition-tolerant shrub species like A. unedo are more adapted to open conditions. To maximize sapling survival and growth, we recommend preserving the shrubby understorey when present.
\end{abstract}

Keywords: Resprouters, tree regeneration, Pinus halepensis, thinning, resource-based model, forest diversification 


\section{Declaration}

Acknowledgements: The authors are especially grateful to M. Audouard, J.M. Lopez for measurements and fieldwork, K. Villsen for English proofreading, and to two anonymous reviewers who helped to improve the manuscript.

Funding: Acknowledgements are expressed to the French Ministry of Agriculture, which funded the research activities. This study was also supported by the French Ministry of Ecology (MTES/DEB).

Data availability: The datasets generated during and analysed during the current study are available from the corresponding author on reasonable request.

Declaration on conflicts of interest: The authors declare that they have no conflict of interest.

\section{Contribution of the co-authors:}

As follows: M. Helluy -MH; J. Gavinet - JG, B. Prévosto - BP, C. Fernandez - CF.

Methodology: MH, JG, BP; Formal Analysis: MH; Investigation: MH, JG, BP; Data curation: MH, JG, BP; Writing - original draft: MH, BP, JG, CF; Writing - review \& editing: MH, JG, BP; Supervision: BP, CF; Project Administration: BP; Funding acquisition: MH, BP. 


\section{INTRODUCTION}

Disturbances associated with climate change, and especially droughts, are the main concern for the future of Mediterranean forests (Peñuelas et al., 2017). In particular, the cumulative effects of droughts and wildfires may lead to important disruptions of ecosystem functioning including the loss of resilience linked to an increased risk of soil erosion, destruction of sources of diaspores and the deterioration of plants' resprouting capacity (Batllori et al., 2017; Cramer et al., 2018). In fact, plant recruitment is expected to decrease under climate change, raising concerns about forest regeneration (Lloret et al., 2004) after major disturbances. Revegetation is one of the management strategies that can be used to restore Mediterranean forest cover (Lindner et al., 2010; Vilà-Cabrera et al., 2018). Mediterranean pines were traditionally used for the restoration of degraded land, due to their large edaphic plasticity, drought tolerance and ability to quickly restore forest cover (Pausas et al., 2004). Moreover, with recent agricultural land abandonment Mediterranean pines such as Aleppo pine (Pinus halepensis Mill.) are now predominant in Mediterranean landscapes, reflecting their large colonising capacity (Quezel et al., 1999). These pine forests were expected to facilitate the establishment of late-successional broadleaved species (Barbéro et al., 1998) although this process can be slow due their low dispersal ability (Puerta-Piñero et al., 2012) and their high vulnerability to drought at early life stage (Zavala et al., 2000). These broadleaved species are known to increase ecosystem resilience mainly through their resprouting capacity after disturbances such as fire (Terradas, 1999). Therefore, understanding the factors that control the early growth and survival of these species in pine forests as well as their ecological requirements are of importance to develop strategies that enhance forests' resilience.

Seedling or sapling survival and growth and therefore regeneration depend on many interacting parameters, and most of them are controlled directly or indirectly by overstory cover. Several studies have found a negative effect of pine cover on seedling establishment (e.g. Bellot et al., 2004; Maestre et al., 2003), but this effect can change as pines density varies (Gavinet et al., 2015; Monnier et al., 2012; Prévosto et al., 2011). Indeed, stand density has a direct impact on forest microclimate: thinning leads to an increase of light in the understorey (Ma et al., 2010; Rodríguez-Calcerrada et al., 2008) as well as an increase in the soil water content (Bréda et al., 1995; Simonin et al., 2007). Many studies have shown that light availability is the main variable that drives sapling survival and growth, with high species-specificity of light requirements (Kobe et al., 1995; Kunstler et al., 2005; Ricard et al, 2003; Kobe, 1999), while drought is a major constraint for most species in water-limited environments (Gómez-Aparicio et al., 2008; Kolb et al., 2020; Zavala et al., 2000). Developing resource-based models can 
therefore help to understand seedling's requirements in order to define safe microsites for planting and adequate overstory management depending on the target species.

Thinning can also lead to the development of an abundant shrubby understorey, which further influences seedling establishment through a direct impact on forest microclimate. For instance, Giuggiola et al. (2018) and Prévosto et al. (2020) illustrated an increase of soil moisture after understorey removal, suggesting that the presence of a dense understorey in drought-prone forests could exert a detrimental effect on growth. However, the shrub layer can also buffer extreme air temperature and evaporative demand, which may benefit seedling development (L. Gómez-Aparicio et al., 2008; Prévosto et al., 2020). The balance between the positive and negative effects of shrubs on seedlings may depend on species or climate, highlighting the need to integrate the understorey in models of seedling development to fully capture the effects of thinning on regeneration success.

The present study examined the effect of light availability, water stress, and understorey shrub cover on the survival and growth of three broadleaved species beneath an Aleppo pine overstory. These species were initially introduced under contrasted pine cover conditions (dense, medium or low cover) and in open areas to promote the diversity and resilience of the forest ecosystems. Our three target species were one shrub - Arbutus unedo, and two trees - Fraxinus ornus and Sorbus domestica. They are naturally found in the Mediterranean region, although they have a scattered distribution within the forests and shrublands of our study area due to a long history of anthropogenic disturbances and their ecology is still poorly known (Gavinet et al., 2015). We developed a modelling approach to predict saplings survival and height growth, using light transmittance, a water stress index (WSI) induced by soil and climatic factors, as well as shrub cover as predictors. We hypothesised i) that increasing light availability would have a positive effect on growth and survival but that this effect would be more pronounced for the shrub species Arbutus unedo than for the other two tree species, which are depicted as more shade-tolerant (Rameau et al., 2008) ii) that water stress would limit survival and growth particularly for the two tree species whereas the shrub species would be less severely impaired iii) a negative effect of the shrub cover on survival.

\section{MATERIAL \& METHODS}

\subsection{Study site and experimental design}

The study site was located in Southern France, approximately $30 \mathrm{~km}$ northwest of Marseille $\left(43^{\circ} 27^{\prime} 0^{\prime \prime} \mathrm{N}\right.$; $5^{\circ} 2^{\prime} 24^{\prime \prime} \mathrm{E}$ ) in a flat area at a mean altitude of $130 \mathrm{~m}$. The climate is Mediterranean with a summer drought period and cool, wet winters. Mean annual temperature is $15.3^{\circ} \mathrm{C}$ (Istres weather station, 1985-2014) and mean annual precipitation is $562 \mathrm{~mm}$ with high inter-annual variability. Soils are calcareous with a sandy-loam texture and a 
mean depth of $\sim 60 \mathrm{~cm}$. We selected a forest area covered by a monospecific even-aged ( 60 years old) Pinus halepensis Mill. tree layer, that established naturally after agricultural abandonment about 60 years ago. The understorey was mainly composed of shrubs (Quercus coccifera, Phillyrea angustifolia, Rosmarinus officinalis, Cistus albidus) and scarce herbaceous plants (mainly Brachypodium retusum). Pine stands were thinned in 2007, leading to four different pine cover treatments: (i) light pine cover (basal area: $10.2 \mathrm{~m} / \mathrm{ha}$ ), (ii) moderate pine cover $\left(19.2 \mathrm{~m}^{2} / \mathrm{ha}\right)$, (iii) dense pine cover $\left(32.0 \mathrm{~m}^{2} / \mathrm{ha}\right.$; no thinning). We added a fourth treatment (iv) open conditions, by selecting a nearby treeless open area with a discontinuous shrub layer in which shrub cover was entirely removed and kept free of shrub encroachment by clearing shrub each year. Each pine cover treatment was replicated in four $25 \times 25 \mathrm{~m}$ plots and we used four $6 \times 20 \mathrm{~m}$ plots in the open area surrounded by a 5-meter-wide buffer zone (Online Resource 1). In February 2016 in the forest area, the shrub layer in the light and moderate pine cover treatments was manually removed on half of the surface of each plot, while the other half was left untouched. Shrub regrowth was suppressed each year during the winter period in the shrub removal treatments. Shrub cover was almost null under the dense pine cover (no thinning) and was not manipulated. The percentage of shrub cover was visually estimated each year for each plot without shrub removal treatment. (Table 1).

Seeds of Arbutus unedo, Fraxinus ornus and Sorbus domestica were collected at different sites sharing similar ecological conditions. The seeds were then germinated and cultivated in a nursery for 1 year, to eventually be transplanted in the field in November 2009. 18 seedlings per species and per plot were planted in holes dug manually distributed along 7 transects in each plot of the pine forest while a total of 20 seedlings per species were planted using the same method in each plot of the open area. The seedlings were immediately cut at $10 \mathrm{~cm}$ to limit the transplant shock. Plots were fenced to avoid predation by large animals.

The saplings were individually tagged and sapling survival, stem height and basal diameter were recorded every year from 2010 to 2018. Only measurements from 2012 to 2018 were used for this study, in order to avoid the shock of transplantation of the two first years. However, due to the slow growth in diameter of the study species and the shrubby form of $A$. unedo, only the height growth was investigated in this study.

\subsection{Measurements and modelling of environmental variables}

\section{Transmittance}

Transmitted radiation was measured every minute for 48h during two successive clear days of April 2017 in 9 plots in the forest area using 6 solarimeter tubes (DPAR/LEC1C, Solem S.A., France) per plot - below pine cover but above shrub canopy - and 2 solarimeter tubes in open conditions, in order to compute transmitted 
radiation. A relationship between pine stand basal area and transmittance was then established to model the change in transmitted radiation through time for each plot. These computed transmittance values below pine canopy were later used in the survival and growth in height models.

Water balance model and Water Stress Index (WSI)

We developed a two-strata forest water balance model (i.e. including understorey properties, see Helluy et al., 2020 for details) based on Granier et al., (1999). The model uses daily temperature and rainfall data as inputs, as well as some site and stand parameters such as soil depth, maximum and minimum extractable soil water (from soil texture analysis), fine root distribution soil porosity and stand Leaf Area Index (LAI). Istres weather station (12 km NW of the site) provided the data over the entire study period and global radiation data were collected from Marignane station (14 km E of the site). The Potential Evapotranspiration (PET) was computed using the radiation-based method of Turc (1961) (see Online Resource 2 for variations of PET from 2012 to 2018). Soil samples were collected in 2014 and 2017. In 2014, 2 plots per treatment were sampled; in each of the selected plots, 6 soil samples at three soil depths were collected for texture analysis. In 2017, 5 soil pits were dug into the treatments and 30 soil samples of constant volume (3 soil depths and 2 samples per depth) were collected to measure the bulk density, the content in coarse elements and in fine roots. The soil properties were considered as constant among the plots, except for soil depth. Soil water holding capacity available to plants was computed for each soil layer (Jabiol et al., 2009) and aggregated at the plot scale. Transmitted radiation, (as measured above) was used to compute the LAI according to the Norman \& Jarvis (1975) equations for both pine and shrub canopies. The modelled LAI was later used to compute the rainfall interception of the Aleppo pine canopy and the understorey using the model proposed by Molina \& del Campo (2012) and the transpiration according to the method described in Granier et al. (1999). Lastly, we computed daily variation in the Relative Extractable Water (REW, between 0 and 1), which is the extractable water standardized by the maximum extractable water (Online Resource 2).

An annual Water Stress Index (WSI) using the REW values was then computed for each plot and each year. We defined a drought event as the moment when REW drops below 0.4, as proposed by Granier et al., (1999). During preliminary analyses, we tested two WSIs: one that represents only drought duration - successfully used to predict pine tree growth in a previous analysis on the same site (Helluy et al., 2020) - and a second one that represents both drought duration and intensity (equation 1).

(1) $W S I=\sum\left(0.4-R E W_{i}\right)$ for $\quad R E W_{i} \leq 0.4$ 
In this study the second WSI performed as well as or better than the first one, and was therefore selected.

Table 1: Environmental and stand characteristics for each treatment (Mean \pm standard error) in 2016, before shrub removal. WSI: water stress index (see equation 1).

\begin{tabular}{lcccc}
\hline & Dense cover & Moderate cover & Light cover & Open conditions \\
\hline Pine basal area $\left(\mathrm{m}^{2} / \mathrm{ha}\right)$ & $37 \pm 0.9$ & $28 \pm 1.5$ & $17 \pm 0.3$ & 0 \\
Transmittance & $0.09 \pm 0.01$ & $0.12 \pm 0.01$ & $0.24 \pm 0.04$ & 1 \\
WSI & $74.4 \pm 2.0$ & $69.7 \pm 2.4$ & $59.4 \pm 3$ & 72.4 \\
Shrub cover $(\%)$ & $12.5 \pm 2.9$ & $33.1 \pm 2.9$ & $46.8 \pm 2.8$ & 0 \\
\hline
\end{tabular}

\subsection{Sapling survival}

We first used survival analysis to test whether the treatments and the species identity had an effect on saplings survival between 2012 and 2018. The survival data are right-censored as a large part of the saplings survived past the end of the study. We used Kaplan-Meier curves to show differences in survival within species and treatments, using the R package \{survival\} (Therneau, 2015; Therneau \& Grambsch, 2000). To analyse the influence of environmental variables on seedling survival, we could not use log-rank tests because the proportional hazards (PH) assumption was not verified (Rulli et al., 2018). Therefore, differences in survival, per species, between the cover treatments were determined by post-hoc Tukey tests on a Generalized Linear Model (GLM) with a binomial distribution, using the R package \{emmeans \} with Tukey corrections (Lenth, 2020).

To characterise the effects of the environmental and dimension variables (transmittance, WSI, shrub cover and past height of the individual) on survival, we produced Cox and Accelerated Failure Time models but the conditions for these models were not met due to the small number of death events per species ( 10 for A. unedo; 20 for $F$. ornus; 27 for $S$. domestica). Instead, we used a generalized linear model (GLM) with a binomial distribution. Each individual sapling was associated with a mean value of transmittance and WSI (computed at plot level). Because of the small number of death events per species we chose to only fit survival models with one covariate at a time to avoid convergence issues (Riley et al., 2019).

\subsection{Sapling height growth}

Linear models using the $\{$ stats $\} \mathrm{R}$ package were used to explore the relationship between sapling annual height growth and the different environmental variables. As the environmental variables were computed at the plot level, we averaged the saplings height growth per plot and per year. Linear regressions were performed to test the 
effect of transmittance, WSI, shrub cover and past height (mean height of the previous year) on the mean height growth. Natural logarithm transformations were used to satisfy the assumptions of linearity and normality of the residuals, the 'LogSt' function from the \{DescTools\} package (Signorell et al., 2019) was used to account for null values of shrub cover and height growth.

To study the relationship between height growth and each environmental variable, we first performed one-variable models. Different mathematical relationships were tested and selected using the Akaike's Information Criterion (AIC) to find the best suited one for each variable and each species (see Online Resource 3 for details). All the possible combinations of variables were tested (with additive effects solely, equation 2):

(2) $\log (d H)=k+\propto \log (H)+\beta \log (T)+\gamma \log (W S I)+\delta \log (S)+\varepsilon$

Where $k, \alpha, \beta, \gamma$ and $\delta$ are the fixed parameters, $d H$ the height increment $(\mathrm{cm}), H$ the past height (cm), WSI the water stress index, $\mathrm{S}$ the shrub cover $(\%)$ and $\varepsilon$ is the residual error. The optimal model was selected using the AIC with maximum likelihood fitting, one-level and two-level interactions were then tested on the best performing model. Similar to the survival analysis, an explanatory variable was only considered as a good predictor if including that variable in the model resulted in a reduction of AIC of at least two points (Burnham \& Anderson, 2004). The normality of the residuals and multi-collinearity of the explanatory variables were checked using a QQ-plot and the Variance Inflation Factor $(<3)$, respectively.

To visualise the effect of the selected variables on height growth, effect plots were produced using the $\mathrm{R}$ package $\{$ effect $\}$ (Fox \& Weisberg, 2018b, 2018a). Specifically for these effect plots, we chose to scale the height growth and the explanatory variables by subtracting the mean and dividing by the standard deviation. This allowed us to compare the different variable effects on standardized height growth on the same scale.

\section{RESULTS}

\subsection{Sapling survival between 2012 and 2018}

Survival was influenced by both species and pine treatments (Figure 1). For F. ornus, survival in 2018 was found to be significantly lower in the open treatment and the other cover treatments (post-hoc Tukey tests, p-value $<0.05)$; indeed it presented the highest survival rate for all treatments $(\sim 96 \%)$ except for the open treatment where survival dropped from $94 \%$ in 2017 to $75 \%$ in 2018. S. domestica only exhibited significant differences in survival in 2018 between the light and the dense cover treatments, as well as between the light and the open cover treatments (post-hoc Tukey tests, p-value < 0.05). S. domestica's highest survival rate was found in the light pine cover 
treatment (95\% in 2018), while it decreased between 2016 and 2018 in the moderate pine cover treatment (86\%) and the open treatment (72\%). Both S. domestica and A. unedo presented a consistent decrease in survival between 2012 and 2018 under dense pine cover, reaching their lowest survival rate in 2018 (56\% and 17\%, respectively). In all other pine cover treatments, $A$. unedo was above $75 \%$ (77\% under moderate pine cover, $84 \%$ in the open, 90\% under light cover). This is consistent with the fact that $A$. unedo showed significant differences in survival in 2018 between the dense cover treatment and all of the other cover treatments (post-hoc Tukey tests, p-value < $0.04)$.
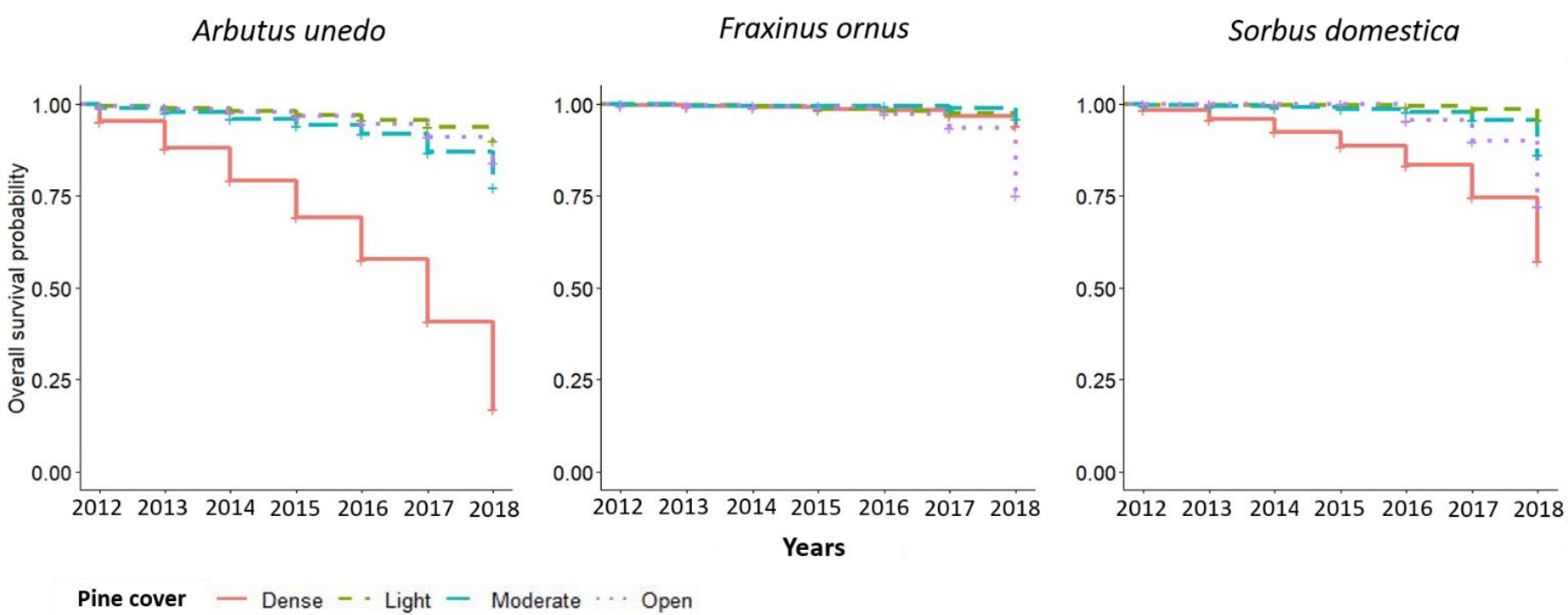

Figure 1: Probability of sapling survival from 2012 to 2018.

\subsection{Survival models}

The influence of the environmental factors on survival was variable. Transmittance and shrub cover did not have a significant effect on $A$. unedo survival while both transmittance and shrub cover had a significant effect on $F$. ornus and $S$. domestica (Table 2, $P$-value $<0.01$ ). For these two latter species, transmittance had a negative effect on survival i.e. the probability of survival decreased as transmittance increased (Figure 2, Table 2, OR $<1$ ), while shrub cover had a positive impact on survival i.e. the probability of survival increased as the shrub cover increased (Table 2, OR > 1). Concerning the effect of water stress, WSI had a significant negative impact on both A. unedo and $S$. domestica (Table 2; OR $<1$ ), while it did not have a significant effect on F.ornus survival. The negative effect of WSI was stronger for A. unedo than for S. domestica, especially when WSI > 60 when A. unedo survival declined (Figure 2). 
Table 2: Estimated coefficients, Odd Ratio (OR), standard errors (Std. errors) and p-values for the single-variable survival model, for each species (for all species, the best survival model is indicated in bold, see Online Resource 4). WSI: water stress index.

\begin{tabular}{lrcccc}
\hline Species & Models & Estimates & OR & Std.errors & P.value \\
\hline A.unedo & Transmittance & 1.5298 & 4.6170 & 1.0886 & 0.16 \\
& Shrub cover & 0.08076 & 1.0841 & 0.0430 & 0.0607 \\
& WSI & $\mathbf{- 0 . 1 6 7 1 9}$ & $\mathbf{0 . 8 4 6 0}$ & $\mathbf{0 . 0 4 3 5}$ & $\mathbf{0 . 0 0 0 1 2} * * *$ \\
\hline F.ornus & Transmittance & $\mathbf{- 2 . 6 1 2 6}$ & $\mathbf{0 . 0 7 3 3 4}$ & $\mathbf{0 . 6 2 4 4}$ & $\mathbf{2 . 8 6 e - 0 5} * * *$ \\
& Shrub cover & $\mathbf{0 . 1 5 9 0 2}$ & $\mathbf{1 . 1 7 2 3}$ & $\mathbf{0 . 0 5 3 1}$ & $\mathbf{0 . 0 0 2 7 9} * *$ \\
& WSI & -0.01273 & 0.98734 & 0.03321 & 0.7014 \\
\hline S.domestica & Transmittance & -1.5055 & 0.2219 & 0.5021 & $0.00272 * *$ \\
& Shrub cover & $\mathbf{0 . 1 0 0 2}$ & $\mathbf{1 . 1 0 5 4}$ & $\mathbf{0 . 0 3 1 8}$ & $\mathbf{0 . 0 0 1 5 9} * *$ \\
& WSI & -0.0539 & 0.9475 & 0.0268 & $0.04468 *$ \\
\hline
\end{tabular}

Significant correlation: $p<0.001^{* * * \prime}, p<0.01^{* * \prime}, p<0.05^{* \prime}$
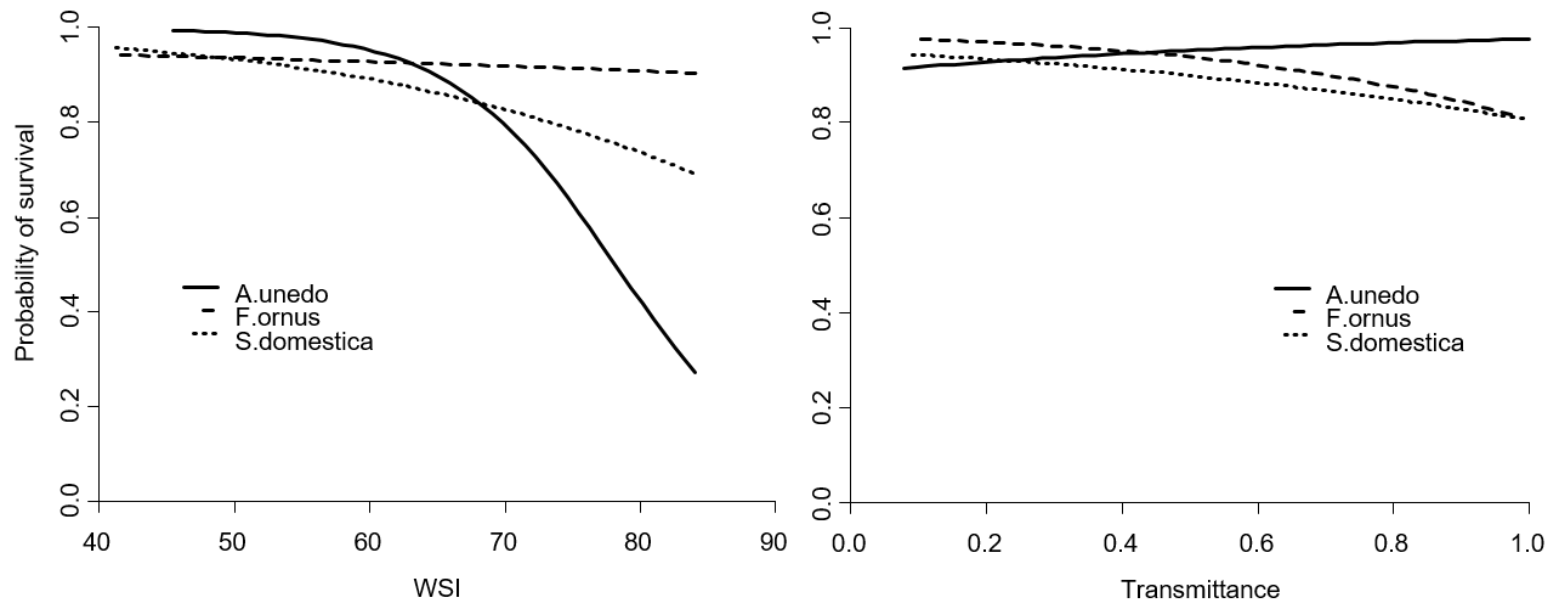

Figure 2: Predicted probability of survival as a function of WSI (left) and transmittance (right), for A. unedo, F. ornus and S. domestica. Based on the models presented in Table 2.

\subsection{Height growth models}

\subsubsection{Influence of each environmental factor}

The three target species responded to light differently. A. unedo reached an asymptote around 0.3 of transmittance, while $F$. ornus and $S$. domestica reached a growth optimum around 0.2 of transmittance which decreased strongly in the open treatment (Figure 3). It must be noted that the gap of transmittance values between 0.3 (light cover treatment) and 1 (open conditions) did not allow us to detect the optimal value with precision. The 
three target species responded negatively to water stress: their height growth decreased as WSI increased. However it must be noted that $F$. ornus' response to water stress was more linear than A. unedo or S. domestica. The shrub cover had a positive effect on the growth of all species although the growth of $F$. ornus decreased in high shrub cover $(>40 \%)$. Finally, past height had a positive influence: growth rapidly increased with increasing past height but this increase was less marked or plateaued to reach an asymptote value after a threshold of about $100 \mathrm{~cm}$ for A. unedo, and $80 \mathrm{~cm}$ for F. ornus and S. domestica.
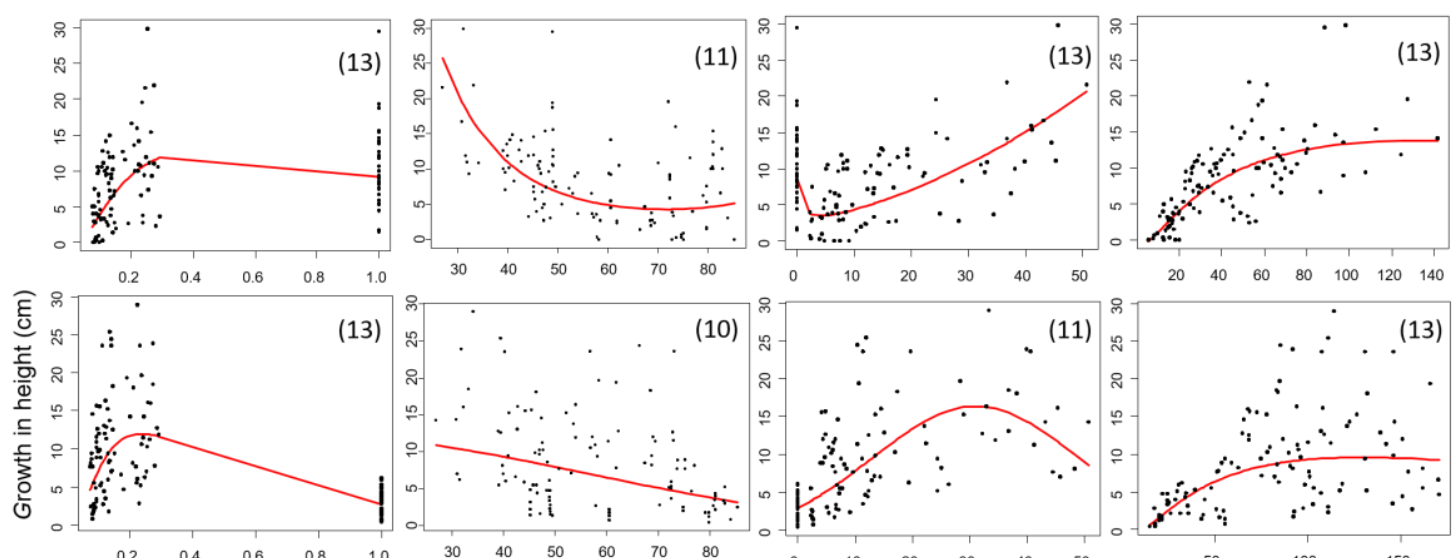

A.unedo
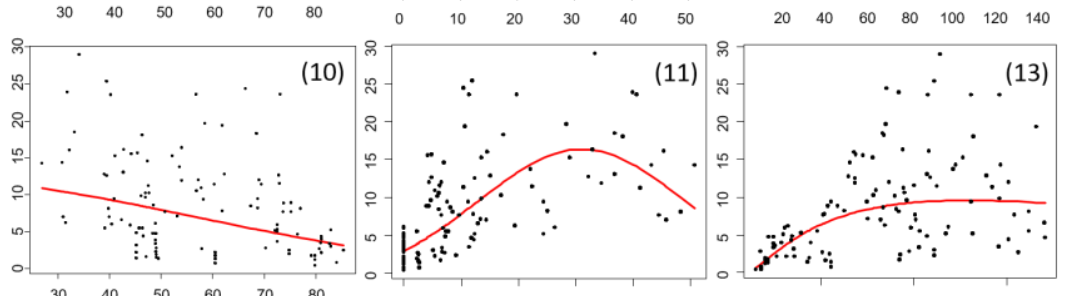

3)

F.ornus
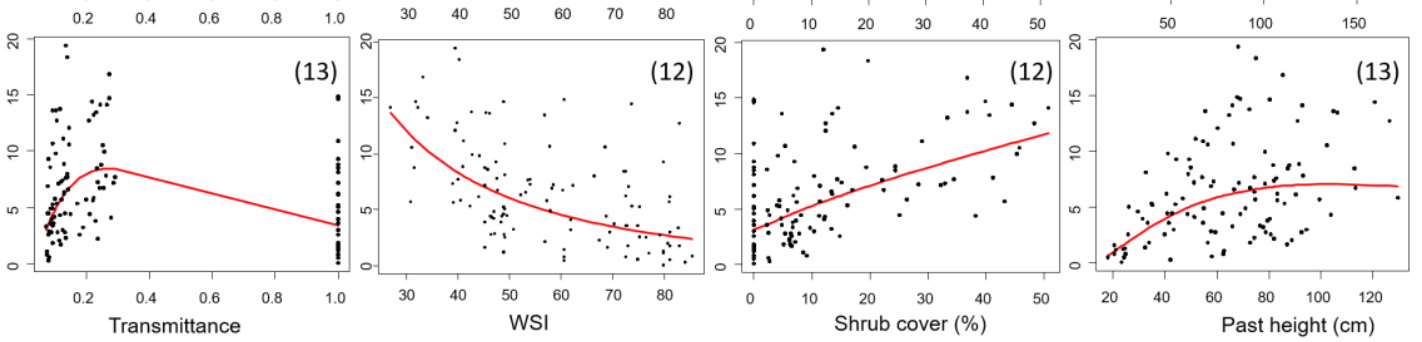

S.domestica

Figure 3: Height growth according to transmittance, WSI (water stress index, see equation (1)), shrub cover and past height for each species. Regression lines are indicated in red. Each point represents the mean value computed at plot level for a specific year (total 16 plots $\times 7$ years $=112$ points). The number on each graph corresponds to the number of the equation used for each respective variable and species (see Online Resource 3 for the details of the equations).

\subsubsection{Growth models including all factors}

We evaluated the growth models that included all factors using AIC (Online Resource 4). The best models are presented in Table 3. For A. unedo, the inclusion of past height dramatically decreased the $\Delta$ AIC (Online Resource 4). Water stress had the second highest impact on $\triangle \mathrm{AIC}$, followed by transmittance. After testing the interactions among these 3 variables, the best model for $A$. unedo included past height, WSI, transmittance and the interaction between past height and WSI. Transmittance had a positive effect on A. unedo height growth: growth was reduced under low transmittance (transmittance $=0.2$ corresponds to a mean growth in height of $0.05 \mathrm{~cm}$ ), and is highest in full light conditions (transmittance $=1$, growth $=0.3 \mathrm{~cm}$ ) (data not shown). Past height had a 
positive effect on height growth particularly below $50 \mathrm{~cm}$, but this relationship was less marked when WSI was low (Figure 4). This illustrates that small A. unedo saplings are very sensitive to drought.

Table 3: Estimated coefficients, standard errors (Std. errors) and P-values for the best growth in height model selected in Online Resource 4, for each species.

\begin{tabular}{|c|c|c|c|c|}
\hline Species & Covariates & Estimates & Std. errors & $P$ value \\
\hline \multirow[t]{4}{*}{ A.unedo } & $\log ($ Past height $)$ & -1.525 & 0.448 & $0.00095 * * *$ \\
\hline & $\log (\mathrm{WSI})$ & -2.254 & 0.413 & $3.13 \mathrm{e}-07 * * *$ \\
\hline & $\log ($ Transmittance $)$ & 0.062 & 0.023 & $0.00946 * *$ \\
\hline & $\log ($ Past height $): \log (\mathrm{WSI})$ & 0.467 & 0.109 & $4.46 \mathrm{e}-05 * * *$ \\
\hline \multirow[t]{2}{*}{ F.ornus } & $\log ($ Shrub cover $)$ & 0.392 & 0.043 & $8.89 \mathrm{e}-15 * * *$ \\
\hline & $\log (\mathrm{WSI})$ & -0.218 & 0.099 & $0.029 *$ \\
\hline \multirow[t]{3}{*}{ S.domestica } & $\log$ (Past height) & -1.638 & 0.918 & 0.0774 \\
\hline & $\log (\mathrm{WSI})$ & -2.632 & 0.943 & $0.0062 * *$ \\
\hline & $\log ($ Past height $): \log (\mathrm{WSI})$ & 0.488 & 0.224 & $0.0316 *$ \\
\hline
\end{tabular}

Significant correlation: $p<0^{* * * *} ; p<0.001^{\prime * * \prime}, p<0.01^{\prime * \prime}, p<0.05^{\prime \prime}$.

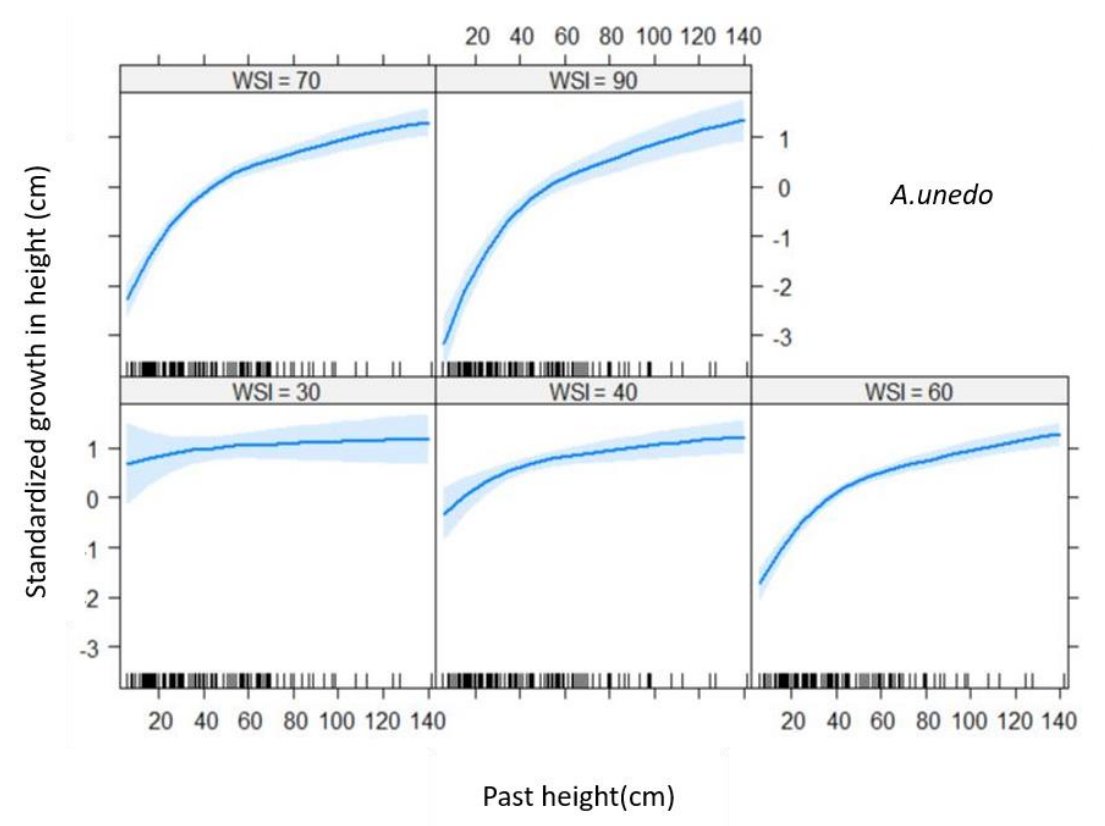

Figure 4: Predicted effects of past height and WSI (water stress index, see equation 1) and their interaction on standardized growth in height for A. unedo; estimated using the best model (Table 3). Shaded areas around the curves represent the confidence intervals of the mean (95\%). Ticks above the x-axis represent the distribution of the measured data.

The best model for F. ornus included shrub cover and WSI (Online Resource 3). The effect of shrub cover and WSI was additive, and they both significantly affected the height growth (Table 3; p-value $<0.05$ ); even though it was less significant for WSI. WSI had a negative effect on standardised height growth, however even at 
high levels of WSI, the standardized growth in height never went below 0 (Fig. 5). Shrub cover had a positive effect on $F$. ornus standardised growth in height, but this positive effect was less marked in plots with shrub cover $>50 \%$.

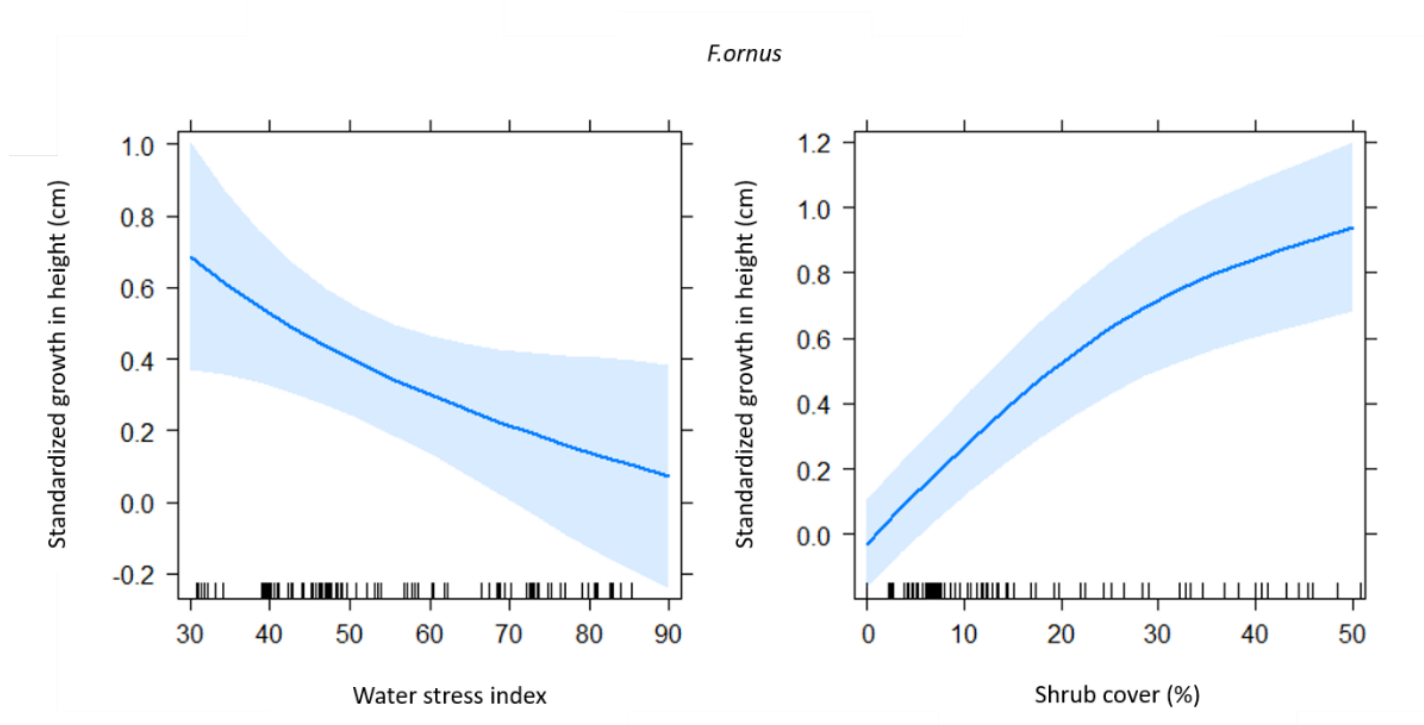

Figure 5: Predicted effects of WSI (water stress index, equation (1)) and shrub cover on standardised growth in height for F. ornus estimated using the best model (Table 3). Shaded areas around the curves represent the confidence intervals of the mean (95\%). Straight lines above the x-axis represent the distribution of the measured data.

For S. domestica, the best model selected with AIC included two covariates: past height and WSI (Online Resource 4). There was an interaction between the two covariates, which had a significant effect on S. domestica's growth in height (Table 3; p-value < 0.01). As for A. unedo, past height had a limited effect on growth in height when WSI was low (if WSI $=30$, standardized growth in height was expected to be around $1 \mathrm{~cm}$ regardless of the past height; Figure 6), however as WSI increases, small trees are expected to be more sensitive to drought with standardised growth being negative for saplings under $60 \mathrm{~cm}$ when WSI $>60$. At the highest levels of WSI, only the tallest trees were expected to have positive height growth (if WSI $=90$, only trees above $120 \mathrm{~cm}$ would present a standardised growth above 0; Figure 6). 


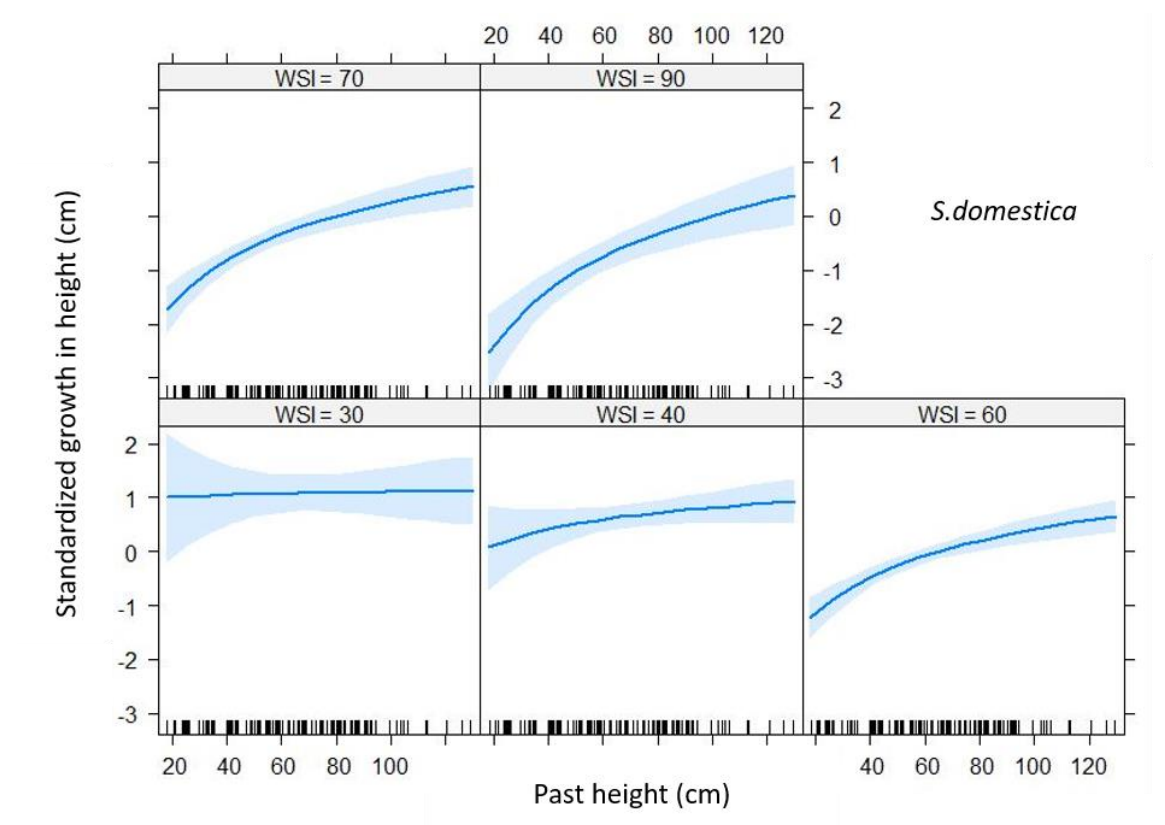

Figure 6: Predicted effects of height and WSI (water stress index, equation (1)) and their interaction on standardised growth in height for S. domestica; estimated using the best model (Table 3). Shaded areas around the curves represent the confidence intervals of the mean (95\%). Straight lines above the $x$-axis represent the distribution of the measured data.

\section{DISCUSSION}

\subsection{Survival}

Contrary to our first hypothesis, we did not detect a positive effect of light availability on all species' survival (Table 2). For F. ornus and S. domestica, transmittance had an overall negative effect on survival probability contrary to many studies that have demonstrated that survival probability usually increases with light availability, (Kobe, 1999; Kunstler et al., 2005; Lin et al., 2002; Zavala et al., 2011). F. ornus is commonly known to be shadetolerant whereas S. domestica has been described as being both shade-tolerant (Gachet et al., 2005; Rameau et al., 2008) and light-demanding, in fact, this species was suggested for afforestation in arid and warm ecosystems (Paganová, 2008). Previous results from this experiment (Gavinet et al., 2016b), have indicated photosynthetic stress in open plots owing to full light conditions and higher temperature fluctuations. For A. unedo, the absence of a statistical link between transmittance and survival could be due to the small number of death events within the study period (only 10) that made model fitting more difficult. The absence of a statistical link between transmittance and survival could also be due to A. unedo's relatively high plasticity and capacity for maintaining itself both in the understorey and in full light conditions in the study region.

We found a negative influence of water stress on sapling survival in A. unedo and S. domestica. This is in accordance with previous studies that have emphasized drought as a major limiting factor that causes sapling 
mortality in various Mediterranean species, including A. unedo (Kolb et al., 2020; Maranón et al., 2004; SánchezGómez, Valladares, \& Zavala, 2006). However, water stress did not have any effect on sapling survival in F. ornus, despite previous studies that have reported that F. ornus and A. unedo have similar water potential values at which $50 \%$ of conductivity is lost due to embolism (about -3.0 to $-3.3 \mathrm{Mpa}$ ) possibly indicating a similar drought resistance (Martínez-Vilalta et al., 2002; Petruzzellis et al., 2018). A deeper root development in the shade-tolerant F. ornus may have allowed seedlings to remain above lethal thresholds. The small number of death event does not provide a clear answer. Further studies over a longer period are needed to better explore the drought resistance and shade tolerance of these species.

Finally and contrary to our third hypothesis, the shrub cover was found to have a positive impact on F. ornus and S. domestica survivorship, indicating a facilitating effect. Indeed, in Mediterranean areas seedling survival is often found to be facilitated by shrub cover (Castro \& Zamora, 2004; Gavinet et al., 2016; Sánchez-Pinillos et al., 2018). This may be due to a buffering effect of the shrubby understorey on microclimatic variables (Prévosto et al., 2020; Giuggiola et al., 2018; Kovács et al., 2017). In a field experiment in Mediterranean montane ecosystems, Gómez-Aparicio et al. (2005) found that microclimate amelioration induced by shrubs led to a reduction of leaf temperature and transpiration losses, which improved the water status of the seedlings and consequently led to greater seedling survivorship. Another study directed on our study site highlighted the buffering capacity of the shrub layer on microclimatic variables including air temperature, vapour pressure deficit, and air relative humidity (Prévosto et al., 2020). We can therefore hypothesize that these microclimatic effects of the shrub layer offset resource limitations (e.g. light attenuation, rainfall interception) leading to a global facilitating effect on seedling survival.

It should be noted that the survival models were only fitted with one variable at a time. As the variables were correlated, this should be taken into account when interpreting the results. For example, transmittance was correlated with water stress (Pearson correlation: 0.35), as well as to shrub cover (Pearson correlation: -0.54); so part of its effect on survival could be integrated into the WSI and shrub effect on survival. Thus, further studies would be needed to precisely disentangle the link between light, water, shrub cover and sapling survival.

\subsection{Height growth}

Height growth in F. ornus and S. domestica peaked around 30\% light (corresponding to light pine cover) whereas growth was reduced at low light and in full light (open conditions). Zavala et al. (2000) also found that seedlings of Quercus ilex attained their maximum growth at an intermediate level of light availability (36\% of 
PAR), with decreasing values at higher levels. On the contrary, A. unedo exhibited low growth at low light levels, and high growth at intermediate and high light levels, with no growth reduction in full light conditions. This is consistent with a previous study on the sa me study site, which suggested that both F. ornus and S. domestica were not only shade-tolerant, but also photoinhibition-intolerant species; while A. unedo appeared to be more lightdemanding and photoinhibition-tolerant and was thus favoured in open conditions (Gavinet et al., 2016b). This adaptation can be due to specific anatomical and physiological features at the leaf level, conferring to A. unedo an intermediate status between drought semi-deciduous and sclerophyllous species (Gratani \& Ghia, 2002).

However, unlike A. unedo, F. ornus' and S. domestica's best height growth models (including all the environmental factors tested in this study) did not include transmittance, despite the fact that light is known to be a major limiting resource for growth of understorey juve nile trees (e.g. Delagrange et al., 2004; Maranón et al., 2004; Ricard et al., 2003). One explanation could be that light is not the most prevailing limiting resource in Mediterranean ecosystems, and competition for light might be less intense due to lower leaf densities (Coomes \& Grubb, 2000) in particular for F. ornus and S. domestica, which are often depicted as more shade-tolerant than $A$. unedo. It was also noteworthy that light influence was highly non-linear for F. ornus and S. domestica as growth is reduced at both ends of the light gradient (Fig. 3) whereas this was not the case for A. unedo.

There is a predominance for belowground competit ion in water-limited ecosystems (Pretzsch \& Biber, 2010; Schwinning \& Weiner, 1998), and many studies found that drought is a major constraint for seedling and sapling height growth in Mediterranean ecosystems (Kolb et al., 2020; Maranón et al., 2004; Pinto et al., 2012; Villar-Salvador et al., 2012; Zavala et al., 2000). For all species, we observed lower growth at high levels of water stress and vice versa (figure 3) and the best models for height growth all included water stress. In the case of A. unedo and S. domestica, small saplings were more affected by increasing water stress compared to tall saplings. Indeed, plant dimensions - including height - is a factor that integrates many parameters. In the case of pioneer Mediterranean pine species, Villar-Salvador et al. (2012) found evidence of a positive effect of seedling size on seedling water status, using an ecophysiological model. In this framework, an increase of seedling size is linked to an increase in the root system size, which leads to an increase in water uptake and thus improves the water status of the seedling, leading to higher photosynthetic rate and higher growth. This could explain the lower sensitivity of tall seedlings to water stress on our study site. Nonetheless, further work exploring the allocation trade-off between the root system and the aerial system is needed. 
Finally, shrub cover had a global positive effect for all species, but was only selected in the growth model for F. ornus. Shrub cover can be a good indicator of light availability below pine canopies, as it increases as the pine cover decreases and consequently, when transmittance increases. Moreover, as for seedling survival, shrubs are known to have a facilitating effect on seedling growth in some species (Castro \& Zamora, 2004; Lines et al., 2019; Sánchez-Pinillos et al., 2018), leading to an increase in height growth. In fact, shrubs can physically limit the lateral expansion of seedling and can modify the microclimatic conditions around them, especially light availability and quality. These modifications can lead to the enhancement of stem elongation whereas diameter growth is often unchanged or even decreased. The growth response to shrub cover was probably amplified for F. ornus compared to the two other species by the fact that its growth was the most severely limited in the open plots (i.e. full light but no shrubs).

\section{Conclusion}

Our results are consistent with a previous study of A. unedo, F. ornus and S. domestica seedlings (Gavinet et al., 2016b), and enable us to propose management strategies in order to enhance the diversification and the resilience of the Mediterranean pine forests. Dense pine stands, by restricting light availability, need to be thinned to reach a moderate or light pine cover (from 20 to $35 \%$ of full light availability) before introducing broadleaved saplings. Shade-tolerant tree species such as F. ornus and S. domestica seem to be more suited to moderate and light cover, while photoinhibition-tolerant shrub species such as A. unedo appear to be more adapted to open conditions. To maximize saplings survival and growth, if present, we recommend preserving the shrubby understorey, although shrub cover above $30 \%$ could be less favourable as was recorded for F. ornus. It must be noted that the overstorey and understorey are also involved in many processes not investigated in this study such as the control of microclimatic factors (e.g. air temperature, air humidity, VPD), its effect on herbivory and pathogens and its role as a reservoir of biodiversity. The production of survival and growth models as a function of the main environmental factors is a first step to develop a more global modelling approach to predict the development of understory species in Mediterranean forest systems under a changing climate.

\section{BIBLIOGRAPHY}

Barbéro, M., Loisel, R., Quézel, P., Richardson, S. M., \& Romane, F. (1998). Pines of the Mediterranean Basin. In D. M. Richardson (Ed.), Ecology and Biogeography of Pinus (pp. 153-170). Cambridge: Cambridge University Press.

Batllori, E., Dećaceres, M., Brotons, L., Ackerly, D. D., Moritz, M. A., \& Lloret, F. (2017). Cumulative effects of fire and drought in Mediterranean ecosystems. Ecosphere, 8(8). https://doi.org/10.1002/ecs2.1906 
Bellot, J., Maestre, F. T., Chirino, E., Hernández, N., \& De Urbina, J. O. (2004). Afforestation with Pinus halepensis reduces native shrub performance in a Mediterranean semiarid area. Acta Oecologica, 25(1-2), 7-15. https://doi.org/10.1016/j.actao.2003.10.001

Bréda, N., Granier, A., \& Aussenac, G. (1995). Effects of thinning on soil and tree water relations, transpiration and growth in an oak forest (Quercus petraea (Matt.) Liebl.). Tree Physiology, 15(5), 295-306. https://doi.org/10.1093/treephys/15.5.295

Burnham, K. P., \& Anderson, D. R. (2004). Multimodel inference: Understanding AIC and BIC in model selection. Sociological Methods and Research, 33(2), 261-304. https://doi.org/10.1177/0049124104268644

Castro, J., \& Zamora, R. (2004). Benefits of Using Shrubs as Nurse Plants for Reforestation in Mediterranean Mountains : A 4-Year Study. Restoration Ecology, 12(3), 352-358.

Coomes, D. A., \& Grubb, P. J. (2000). Impacts of root competition in forests and woodlands: a theoretical framework and review of experiments. Ecological Monographs, 70(2), 171-207.

Cramer, W., Guiot, J., Fader, M., Garrabou, J., Gattuso, J.-P., Iglesias, A., ... Xoplaki, E. (2018). Climate change and interconnected risks to sustainable development in the Mediterranean. Nature Climate Change. https://doi.org/10.1038/s41558018-0299-2

Delagrange, S., Messier, C., Lechowicz, M. J., \& Dizengremel, P. (2004). Physiological, morphological and allocational plasticity in understory deciduous trees: Importance of plant size and light availability. Tree Physiology, 24(7), 775-784. https://doi.org/10.1093/treephys/24.7.775

Fox, J., \& Weisberg, S. (2018a). An R companion to Applied Regression. (T. Oaks, Ed.) (3rd Editio). CA.

Fox, J., \& Weisberg, S. (2018b). Visualizing Fit and Lack of Fit in Complex Regression Models with Predictor Effect Plot and Partial Residuals. Journal of Statistical Software, 87(9), 1-27. Retrieved from http://www.jstatsoft.org/v32/i01/

Gachet, S., Véla, E., \& Tatoni, T. (2005). BASECO: A floristic and ecological database of Mediterranean French flora. Biodiversity and Conservation, 14(4), 1023-1034. https://doi.org/10.1007/s10531-004-8411-5

Gavinet, J., Prévosto, B., \& Fernandez, C. (2016a). Do shrubs facilitate oak seedling establishment in Mediterranean pine forest understory? Forest Ecology and Management, 381, 289-296. https://doi.org/10.1016/j.foreco.2016.09.045

Gavinet, J., Prévosto, B., \& Fernandez, C. (2016b). Introducing resprouters to enhance Mediterranean forest resilience: importance of functional traits to select species according to a gradient of pine density. Journal of Applied Ecology, 53, 17351745. https://doi.org/10.1111/1365-2664.12716

Gavinet, J., Vilagrosa, A., Chirino, E., Granados, M. E., Vallejo, V. R., \& Prévosto, B. (2015). Hardwood seedling establishment below Aleppo pine depends on thinning intensity in two Mediterranean sites. Annals of Forest Science, 72(8), 999-1008. https://doi.org/10.1007/s13595-015-0495-4

Giuggiola, A., Zweifel, R., Feichtinger, L. M., Vollenweider, P., Bugmann, H., Haeni, M., \& Rigling, A. (2018). Competition for water in a xeric forest ecosystem - Effects of understory removal on soil micro-climate, growth and physiology of dominant Scots pine trees. Forest Ecology and Management, 409(October 2017), 241-249. https://doi.org/10.1016/j.foreco.2017.11.002

Gómez-Aparicio, L., Pérez-Ramos, I. M., Mendoza, I., Matías, L., Quero, J. L., Castro, J., ... Marañón, T. (2008). Oak seedling survival and growth along resource gradients in Mediterranean forests: Implications for regeneration in current and future environmental scenarios. Oikos, 117(11), 1683-1699. https://doi.org/10.1111/j.1600-0706.2008.16814.x 
Gómez-Aparicio, Lorena, Gómez, J. M., Zamora, R., \& Boettinger, J. L. (2005). Canopy vs. soil effects of shrubs facilitating tree seedlings in Mediterranean montane ecosystems. Journal of Vegetation Science, 16(2), $191-198$. https://doi.org/10.1111/j.1654-1103.2005.tb02355.x

Granier, A., Bréda, N., Biron, P., \& Villette, S. (1999). A lumped water balance model to evaluate duration and intensity of drought constraints in forest stands. Ecological Modeling, 116, 269-283. https://doi.org/https://doi.org/10.1016/S0304-3800 (98)00205-1

Gratani, L., \& Ghia, E. (2002). Adaptive strategy at the leaf level of Arbutus unedo L. to cope with Mediterranean climate. Flora - Morphology, Distribution, Functional Ecology of Plants, 197(4), 275-284. Retrieved from http://linkinghub.elsevier.com/retrieve/pii/S0367253004700274\%5Cnpapers2://publication/doi/10.1078/0367-2530-00041

Helluy, M., Prévosto, B., Cailleret, M., Fernandez, C., \& Balandier, P. (2020). Competition and water stress indices as predictors of Pinus halepensis Mill. radial growth under drought. Forest Ecology and Management, 460(117877). https://doi.org/10.1016/j.foreco.2020.117877

Jabiol, B., Lévy, G., Bonneau, M., \& Brêthes, A. (2009). Comprendre les sols pour mieux gérer les forêts. AgroParisTech. Nancy: AgroParisTech.

Kobe, R. K. (1999). Light gradient partitioning among tropical tree species through differential seedling mortality and growth. Ecology, 80(1), 187-201.

Kobe, R. K., Pacala, S. W., Silander, J. A., \& Canham, C. D. (1995). Juvenile Tree Survivorship as a Component of Shade Tolerance. Ecological Applications, 5(2), 517-532.

Kolb, T. E., Flathers, K., Bradford, J. B., Andrews, C., Asherin, L. A., \& Moser, W. K. (2020). Stand Density, Drought and Herbivory Constrain Ponderosa Pine Regeneration Pulse. Canadian Journal of Forest Research, 10(June 2019), 1-10. https://doi.org/10.1139/cjfr-2019-0248

Kovács, B., Tinya, F., \& Ódor, P. (2017). Stand structural drivers of microclimate in mature temperate mixed forests. Agricultural and Forest Meteorology, 234-235, 11-21. https://doi.org/10.1016/j.agrformet.2016.11.268

Kunstler, G., Curt, T., Bouchaud, M., \& Lepart, J. (2005). Growth, mortality, and morphological response of European beech and downy oak along a light gradient in sub-Mediterranean forest. Canadian Journal of Forest Research, 35(7), $1657-1668$. https://doi.org/10.1139/x05-097

Lenth, R. (2020). emmeans: Estimated marginal Means, aka Least-Squares Means. R package version 1.4.7. Retrieved from https://cran.r-project.org/package=emmeans

Lin, J., Harcombe, P. A., Fulton, M. R., \& Hall, R. W. (2002). Sapling growth and survivorship as a function of light in a mesic forest of southeast Texas, USA. Oecologia, 132(3), 428-435. https://doi.org/10.1007/s00442-002-0986-5

Lindner, M., Maroschek, M., Netherer, S., Kremer, A., Barbati, A., Garcia-Gonzalo, J., ... Marchetti, M. (2010). Climate change impacts, adaptive capacity, and vulnerability of European forest ecosystems. Forest Ecology and Management, 259(4), 698-709. https://doi.org/10.1016/j.foreco.2009.09.023

Lines, E. R., Zavala, M. A., Ruiz-Benito, P., \& Coomes, D. A. (2019). Capturing juvenile tree dynamics from count data using Approximate Bayesian Computation. Ecography, 1-13. https://doi.org/10.1111/ecog.04824

Lloret, F., Penuelas, J., \& Estiarte, M. (2004). Experimental evidence of reduced diversity of seedlings due to climate modification in a Mediterranean-type community. Global Change Biology, 10(2), 248-258. https://doi.org/10.1111/j.13652486.2004.00725.x 
Ma, S., Concilio, A., Oakley, B., North, M., \& Chen, J. (2010). Spatial variability in microclimate in a mixed-conifer forest before and after thinning and burning treatments. Forest Ecology and Management, 259(5), 904-915. https://doi.org/10.1016/j.foreco.2009.11.030

Maestre, F. T., Cortina, J., Bautista, S., \& Bellot, J. (2003). Does Pinus halepensis facilitate the establishment of shrubs in Mediterranean semi-arid afforestations? Forest Ecology and Management, 176(1-3), 147-160. https://doi.org/10.1016/S03781127(02)00269-4

Maranón, T., Zamora, R., Villar, R., Zavala, M. A., Quero, J. L., Pérez-Ramos, I., ... Castro, J. (2004). Regeneration of tree species and restoration under constrasted Mediterranean habitats: Field and glasshouse experiments. International Journal of Ecology and Environmental Sciences, 30(3), 187-196.

Martínez-Vilalta, J., Prat, E., Oliveras, I., \& Piñol, J. (2002). Xylem hydraulic properties of roots and stems of nine Mediterranean woody species. Oecologia, 133(1), 19-29. https://doi.org/10.1007/s00442-002-1009-2

Molina, A. J., \& del Campo, A. D. (2012). The effects of experimental thinning on throughfall and stemflow: A contribution towards hydrology-oriented silviculture in Aleppo pine plantations. Forest Ecology and Management, 269, $206-213$. https://doi.org/10.1016/j.foreco.2011.12.037

Monnier, Y., Prévosto, B., Ripert, C., Corbani, A. C., \& Fernandez, C. (2012). Forest microhabitats differentially influence seedling phenology of two co-existing Mediterranean oak species. Journal of Vegetation Science, 23(2), 260-270. https://doi.org/10.1111/j.1654-1103.2011.01358.x

Norman, J. M., \& Jarvis, P. G. (1975). Photosynthesis in Sitka Spruce (Picea sitchensis (Bong.) Carr): V. Radiation Theory and a Test case. Journal of Applied Ecology, 12(3), 839-878.

Paganová, V. (2008). Ecological requirements of wild service tree (Sorbus torminalis [ L .] Crantz ) and service tree (Sorbus domestica L.) in relation with their utilization in forestry and landscape. Journal of Forest Science, 54(1), 216-226.

Pausas, J. G., Blad, C., Valdecantos, A., Seva, J. P., Fuentes, D., Alloza, J. A., ... Vallejo, R. (2004). Pines and oaks in the restoration of Mediterranean landscapes of Spain: New perspectives for an old practice - A review. Plant Ecology, 171(1-2), 209-220. https://doi.org/10.1023/B:VEGE.0000029381.63336.20

Peñuelas, J., Sardans, J., Filella, I., Estiarte, M., Llusià, J., Ogaya, R., ... Terradas, J. (2017). Impacts of global change on Mediterranean forests and their services. Forests, 8(12), 1-37. https://doi.org/10.3390/f8120463

Petruzzellis, F., Nardini, A., Savi, T., Tonet, V., Castello, M., \& Bacaro, G. (2018). Less safety for more efficiency: Water relations and hydraulics of the invasive tree Ailanthus altissima (Mill.) Swingle compared with native Fraxinus ornus L. Tree Physiology, 39(1), 76-87. https://doi.org/10.1093/treephys/tpy076

Pinto, J. R., Marshall, J. D., Dumroese, R. K., Davis, A. S., \& Cobos, D. R. (2012). Photosynthetic response , carbon isotopic composition, survival, and growth of three stock types under water stress enhanced by vegetative competition. Canadian Journal of Forest Research, 344, 333-344. https://doi.org/10.1139/X11-189

Pretzsch, H., \& Biber, P. (2010). Size-symmetric versus size-asymmetric competition and growth partitioning among trees in forest stands along an ecological gradient in central Europe. Canadian Journal of Forest Research, 384, 370-384. https://doi.org/10.1139/X09-195

Prévosto, B., Bousquet-Mélou, A., Ripert, C., \& Fernandez, C. (2011). Effects of different site preparation treatments on species diversity, composition, and plant traits in Pinus halepensis woodlands. Plant Ecology, 212(4), 627-638. https://doi.org/10.1007/s11258-010-9852-4 
Prévosto, B., Helluy, M., Gavinet, J., Fernandez, C., \& Balandier, P. (2020). Microclimate in Mediterranean pine forests : What is the influence of the shrub layer? Agricultural and Forest Meteorology, (107856), 282-283. https://doi.org/10.1016/j.agrformet.2019.107856

Puerta-Piñero, C., Brotons, L., Coll, L., \& González-Olabarría, J. R. (2012). Valuing acorn dispersal and resprouting capacity ecological functions to ensure Mediterranean forest resilience after fire. European Journal of Forest Research, 131(3), 835844. https://doi.org/10.1007/s10342-011-0557-6

Quézel, P., Médail, F., Loisel, R., \& Barbero, M. (1999). Biodiversité et conservation des essences forestières du bassin méditerranéen. Unasylva (FAO).

Rameau, J.-C., Mansion, D., Dume, J., Gauberville, C., Bardat, J., Bruno, E., \& Keller, R. (2008). Flore Forestière Française. Tome 3: Région Méditerranéenne. Paris: Institut pour le Développement Forestier.

Ricard, J.-P., Messier, C., Delagrange, S., \& Beaudet, M. (2003). Do understory sapling respond to both light and below-ground competition?: a field experiment in a north-eastern American hardwood forest and a literature review Jean-Pierre. Annals of Forest Science, 60(2003), 749-756. https://doi.org/10.1051/forest

Riley, R. D., Snell, K. I. E., Ensor, J., Burke, D. L., Harrell, F. E., Moons, K. G. M., \& Collins, G. S. (2019). Minimum sample size for developing a multivariable prediction model: PART II - binary and time-to-event outcomes. Statistics in Medicine, 38(7), 1276-1296. https://doi.org/10.1002/sim.7992

Rodríguez-Calcerrada, J., Mutke, S., Alonso, J., Gil, L., Pardos, J. A., \& Aranda, I. (2008). Influence of overstory density on understory light, soil moisture, and survival of two underplanted oak species in a Mediterranean montane Scots pine forest. Investigación Agraria: Sistemas y Recursos Forestales, 17(1), 31. https://doi.org/10.5424/srf/2008171-01021

Rulli, E., Ghilotti, F., Biagioli, E., Porcu, L., Marabese, M., D’Incalci, M., ... Torri, V. (2018). Assessment of proportional hazard assumption in aggregate data: a systematic review on statistical methodology in clinical trials using time-to-event endpoint. British Journal of Cancer, 119(12), 1456-1463. https://doi.org/10.1038/s41416-018-0302-8

Sánchez-Gómez, D., Valladares, F., \& Zavala, M. A. (2006). Performance of seedlings of Mediterranean woody species under experimental gradients of irradiance and water availability, trade-off and evidence for niche differentiation.pdf. New Phytologist, 170, 795-806.

Sánchez-Pinillos, M., Ameztegui, A., Kitzberger, T., \& Coll, L. (2018). Relative size to resprouters determines post- fi re recruitment of non- serotinous pines. Forest Ecology and Management, 429(July), $300-307$. https://doi.org/10.1016/j.foreco.2018.07.009

Schwinning, S., \& Weiner, J. (1998). Mechanisms determining the degree of size asymmetry in competition among plants. Oecologia, 113(4), 447-455. https://doi.org/10.1007/s004420050397

Signorell, A., \& al., et mult. (2019). DescTools: Tools for descriptive statistics. R Package Version 0.99.27. Retrieved from https://cran.r-project.org/package=DescTools

Simonin, K., Kolb, T. E., Montes-Helu, M., \& Koch, G. W. (2007). The influence of thinning on components of stand water balance in a ponderosa pine forest stand during and after extreme drought. Agricultural and Forest Meteorology, 143(3-4), 266-276. https://doi.org/10.1016/j.agrformet.2007.01.003

Terradas, J. (1999). Holm Oak and Holm Oak Forests: An Introduction. In F. Rodan, J. Rotana, C. A. Gracia, \& J. Bellot (Eds.), Ecology of Mediterranean Evergreen Oak Forests. Ecological studies (Analysis and Synthesis) (Vol. 137, pp. 3-14). Berlin, Heidelberg: Springer-Verlag. https://doi.org/10.1007/978-3-642-58618-7_1 
Therneau, T. (2015). A Package for Survival Analysis in R. Retrieved from url: https://CRAN.R-project.org/package=survival Therneau, T., \& Grambsch, P. (2000). Modeling Survival Data: Extending the Cox Model (Springer). New York.

Turc, L. (1961). Évalutation des besoins en eau d'irrigation, évapotranspiration potentielle. Ann. Agron., 12(1), 13-49.

Vilà-Cabrera, A., Coll, L., Martínez-Vilalta, J., \& Retana, J. (2018). Forest management for adaptation to climate change in the Mediterranean basin: A synthesis of evidence. Forest Ecology and Management, 407(August 2017), 16-22. https://doi.org/10.1016/j.foreco.2017.10.021

Villar-Salvador, P., Puértolas, J., Cuesta, B., Peñuelas, J. L., Uscola, M., Heredia-Guerrero, N., \& Benayas, J. M. R. (2012). Increase in size and nitrogen concentration enhances seedling survival in Mediterranean plantations. Insights from an ecophysiological conceptual model of plant survival. New Forests, 755-770. https://doi.org/10.1007/s11056-012-9328-6

Zavala, M A, Espelta, J. M., \& Retana, J. (2000). Constraints and Trade-Offs in Mediterranean Plant Communities: The Case of Holm Oak-Aleppo Pine Forests. The Botanical Review, 66(March), 119-149.

Zavala, Miguel A., Espelta, J. M., Caspersen, J., \& Retana, J. (2011). Interspecific differences in sapling performance with respect to light and aridity gradients in mediterranean pine-oak forests: Implications for species coexistence. Canadian Journal of Forest Research, 41(7), 1432-1444. https://doi.org/10.1139/x11-050 


\section{APPENDICES}

ONLINE RESOURCE 1: Location of the 12 plots (squares) in the forest area and the open treeless area (in the insert). Treatments are as follows: light pine cover (white squares), moderate pine cover (grey squares) and dense pine cover (black squares).

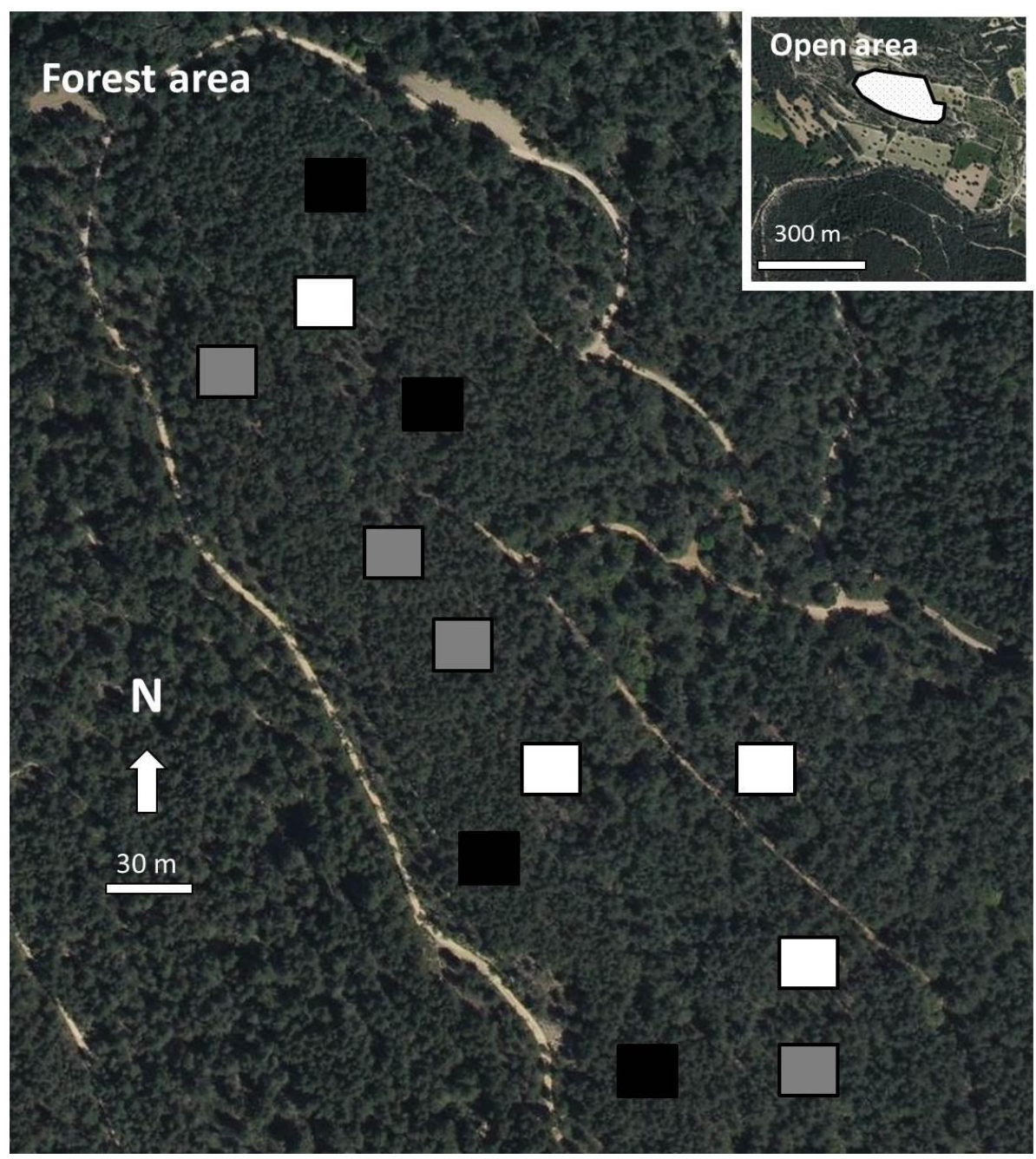



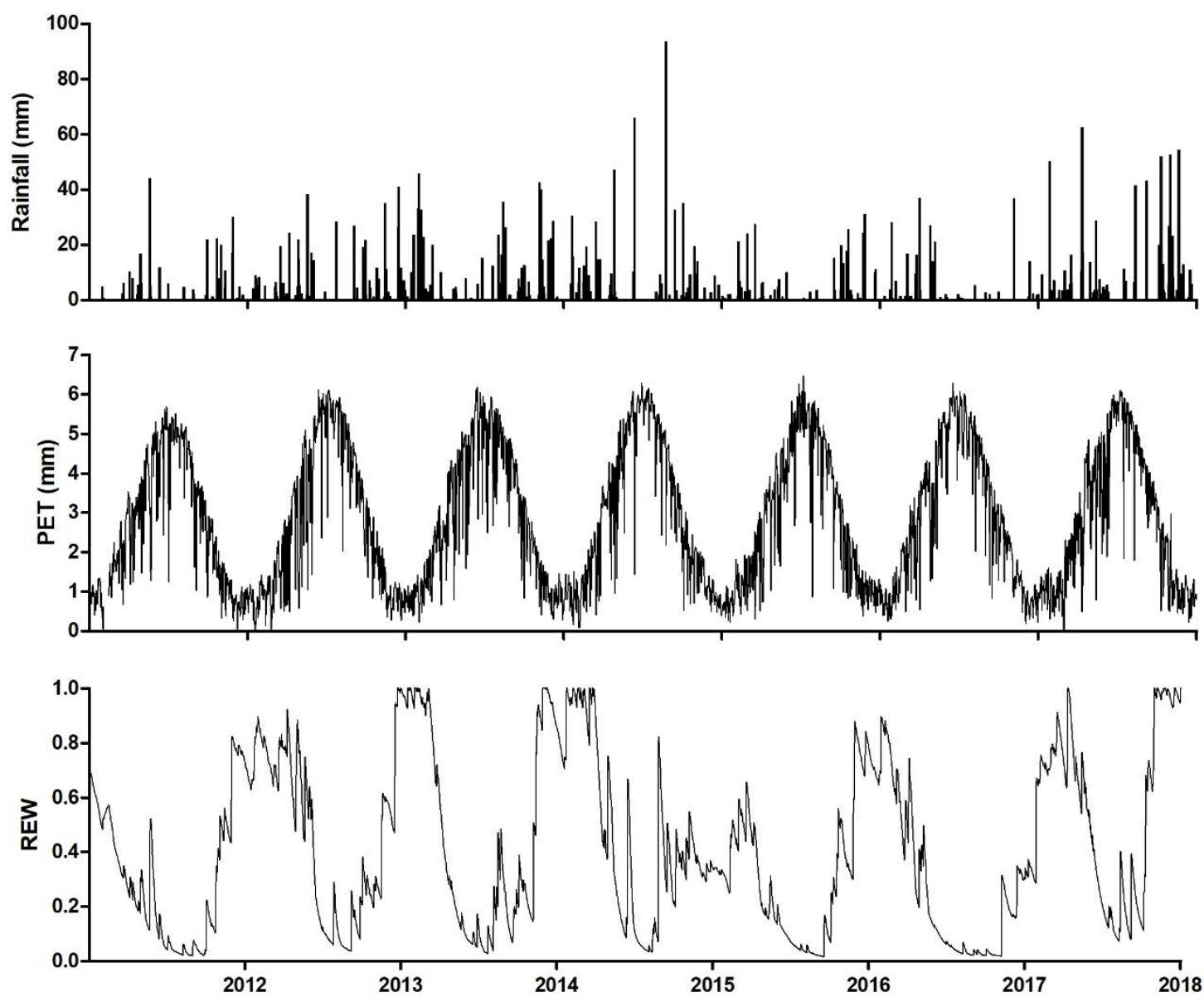

\begin{tabular}{cccccccc}
\hline Year & 2012 & 2013 & 2014 & 2015 & 2016 & 2017 & 2018 \\
\hline Annual rainfall (mm) & 326 & 598 & 797 & 660 & 411 & 311 & 672 \\
\hline
\end{tabular}


ONLINE RESOURCE 3: Mathematical relationships tested for the one-variable models, for each variable and each species (see Figure 3). $\propto, \beta$, and $k$ are the fixed parameters, dheight is the height growth (cm), and "variable" is either one of the environmental variables tested (WSI, Transmittance, Shrub cover), either the height (cm).

(3) $\log ($ dheight $)=\propto$ variable $+k$

(4) dheight $=\propto \log ($ variable $)+k$

(5) $\log ($ dheight $)=\propto \log ($ variable $)+k$

(6) dheight $=\propto$ variable $^{2}+k$

(7) dheight $=\propto$ variable ${ }^{2}+\beta$ variable $+k$

(8) dheight $=\propto \log (\text { variable })^{2}+k$

(9) dheight $=\propto \log (\text { variable })^{2}+\beta \log ($ variable $)+k$

(10) $\log ($ dheight $)=\propto$ variable ${ }^{2}+k$

(11) $\log ($ dheight $)=\propto$ variable ${ }^{2}+\beta$ variable $+k$

(12) $\log ($ dheight $)=\propto \log (\text { variable })^{2}+k$

(13) $\log ($ dheight $)=\propto \log (\text { variable })^{2}+\beta \log ($ variable $)+k$ 
ONLINE RESOURCE 4: Comparison of several alternative height growth models using Akaike's Information Criterion (AIC), for each species. Only models including additive effects are presented in this table. For each species, each height growth model is given a $\triangle A I C$ (values in the table), which corresponds to the differences in AIC with respect to the model with the lowest AIC (supposedly the "best" fitting one). When $\triangle A I C$ among the best models was $<2$ we selected the more parsimonious one. The best fitting models according to this selection are in bold in the table. Models with $2 * 2$ interactions were also tested but are not shown.

\begin{tabular}{llll}
\hline Variables included in the models & A.unedo & F.ornus & S.domestica \\
\hline Null model & 130.68 & 76.90 & 66.08 \\
WSI & 107.03 & 60.05 & 28.51 \\
Transmittance & 113.89 & 57.11 & 65.64 \\
Past height & 37.60 & 24.41 & 30.41 \\
Shrub cover & 131.84 & 2.89 & 40.75 \\
WSI and transmittance & 82.01 & 38.05 & 28.06 \\
Past height and transmittance & 37.59 & 25.68 & 29.77 \\
WSI and past height & 4.09 & 12.92 & $\mathbf{0 . 0 0}$ \\
WSI and shrub cover & 108.08 & $\mathbf{0 . 0 0}$ & 16.58 \\
Past height and shrub cover & 38.33 & 4.34 & 29.76 \\
Transmittance and shrub cover & 87.13 & 4.44 & 36.71 \\
WSI, past height and transmittance & $\mathbf{0 . 0 0}$ & 14.88 & 0.32 \\
WSI, past height and shrub cover & 4.87 & 0.59 & 1.95 \\
Transmittance, past height and shrub cover & 29.90 & 4.95 & 23.60 \\
WSI, transmittance and shrub cover & 71.20 & 1.99 & 16.87 \\
WSI, transmittance, past height and shrub cover & 1.04 & 2.09 & 1.08 \\
\hline
\end{tabular}

